\title{
Comparison of morphine and fentanyl in attenuation of Intra operative stress response under general anesthesia: A randomized double blinded study
}

\author{
R. Krishna Prabu', P. Rani' ${ }^{1}$, N. P. Madhu² \\ ${ }^{1}$ Associate Professor, Department of Anaesthesiology, Sri Venkateshwaraa Medical College and Hospital, Ariyur, Pondicherry - 102, India, \\ ${ }^{2}$ CRRI, Sri Venkateshwaraa Medical College and Hospital, Ariyur, Pondicherry - 102, India
}

\section{A B S T R A C T}

Background: This randomized double blinded study was done to compare the effect of intravenous morphine and fentanyl in attenuation of stress response during surgeries under general anesthesia in adults. The attenuation of stress response was analyzed with changes in serum cortisol and glucose levels one hour after induction of anesthesia. Methods: Fifty consented healthy volunteers in age group 20-50, under ASA I and ASA II posted for elective surgery were included in the study. Two groups of 25 each, group $M$ who received 0.2 $\mathrm{mg} / \mathrm{kg}$ body weight of morphine and group $\mathrm{F}$ who received 2 microgram/ $\mathrm{kg}$ body weight of fentanyl before anaesthetic induction were compared. The members of two groups were randomly allocated and double blinded using sealed envelope technique. Blood samples were collected for baseline glucose and cortisol in all the subjects. One hour after the administration of study drugs, which was given at the time of induction blood samples were collected for analysis of glucose and cortisol. The changes in blood glucose and serum cortisol levels were compared at the end of the study using independent samples ' $t$ ' test. Results: There was no significant difference in blood sugar levels in both groups at the end of 1 hour. But there was significant increase in serum cortisol levels in group $F$ compared to group $M$. Conclusion: This study concludes that morphine is better than fentanyl in attenuation of Intraoperative stress by effectively controlling serum cortisol levels.

Key words: Anesthesia, Fentanyl, Morphine, Stress response, surgery

\section{INTRODUCTION}

Stress response due to surgery and anesthesia has its deleterious effect on various organs because of hyperglycemia and increased cortisol secretion. ${ }^{1}$ Adequate attenuation of stress response can prevent alteration in immune system, hyperglycemia and delay in wound healing. ${ }^{2}$ During stress the release of corticotrophin from the pituitary stimulates cortisol secretion from the adrenal cortex. In pancreas, glucagon is released and insulin secretion is diminished. These leads to increase in circulating cortisol and glucose levels. ${ }^{3}$

The increase in cortisol levels inhibits the accumulation of macrophages and neutrophils into areas of inflammation. ${ }^{4}$ This along with increase in blood sugar interferes with wound healing and increases the incidence of wound infection. So, inadequate attenuation of stress response is associated with altered immune function, hyperglycemia and delayed wound healing in post operative period.

Various modifications in anesthetic techniques, like addition of neural blockade with general anesthesia and use of different opioids to modify the endocrine and metabolic responses had been studied. ${ }^{5}$ It has been known that opioids suppress hypothalamic and pituitary hormones secretion. McDonald and colleagues demonstrated the suppressant effects of therapeutic doses of morphine on hypothalamo-pituitary axis in humans. ${ }^{6}$ 
This study was conducted to compare the effect of intravenous fentanyl and intravenous morphine in attenuation of stress response in adult patients who underwent surgery under general anesthesia. The attenuation of stress response was analyzed based on changes in serum cortisol levels and blood glucose levels in both the groups by comparing baseline values and post anesthetic induction values.

\section{MATERIALS AND METHODS}

This randomized double blinded study was conducted after obtaining Institute's scientific and ethical committee approval. This trial was also registered in clinical trial registry of India [CTRI/2013/05/003691]. 50 healthy adult volunteers of either sex in age group 20-50 years under ASA PS I and II (American Society of Anesthesiologists Physical Status) who presented for elective major surgeries were enrolled in this study after obtaining their informed consent. Patients with associated systemic illnesses, patients with history of bronchial asthma, patients who presented for emergency surgeries were excluded from the study.

The selected patients were randomly divided into two groups, group M and group F. Randomization and blinding was done using sealed envelope technique. All the Patients were premedicated with tablet diazepam $10 \mathrm{mg}$ the night before surgery. Group M received morphine $0.2 \mathrm{mg}$ per $\mathrm{kg}$ body weight and Group F received fentanyl 2 mcg per $\mathrm{kg}$ body weight just before induction.

In the operating room, after securing an intra venous line blood sample was taken for glucose and cortisol analysis (sample 1). The standard monitoring was established with continuous ECG monitoring, automated non-invasive blood pressure, pulseoximeter and post intubation endtidal carbon dioxide. Patients received intravenous (IV) midazolam $1 \mathrm{mg}$ and study drug, either morphine or fentanyl (as labeled in sealed envelope) which was loaded in $5 \mathrm{ml}$ syringe. After pre oxygenation patients were induced with thiopentone sodium $5 \mathrm{mg} / \mathrm{kg}$ body weight. Succinylcholine $2 \mathrm{mg} / \mathrm{kg}$ body weight was given to facilitate endo-tracheal intubation. Anesthesia was maintained with oxygen, nitrous oxide, isoflurane and vecuronium. Hemodynamics and arterial oxygen saturation were recorded at 3 minutes interval. Second sample was taken exactly one hour after induction for analysis of sugar and cortisol. At the end of the surgery, patients were reversed with $50 \mathrm{mcg} / \mathrm{kg}$ neostigmine and $10 \mathrm{mcg} / \mathrm{kg}$ glycopyrrolate and extubated. The sealed envelopes were decoded at the end of the study. The pre-induction and post-induction serum glucose levels and cortisol levels were compared between two groups using independent samples ' $t$ ' test.
Serum glucose levels are indicated in milligram per deciliter $(\mathrm{mg} / \mathrm{dl})$ and cortisol levels in microgram per deciliter $(\mathrm{mcg} / \mathrm{dl})$.

\section{RESULTS}

Patient characteristics were comparable in both the groups. There was no significant difference in hemodynamics data between two groups.

\section{DISCUSSION}

Perioperative surgical stress is characterized by increased secretion of pituitary hormones and sympathetic system

\begin{tabular}{lllccc}
\hline Table 1: Pre-induction glucose levels (in $\mathbf{~ m g / d l )}$ \\
\hline \multicolumn{5}{c}{ Independent samples 't' test } \\
\hline Variable & $\mathbf{N}$ & Mean & Std. Deviation & 't' value & Level of $\mathbf{0 . 0 5}$ \\
\hline Group M & 25 & 97.12 & 16.483 & 0.789 & Not significant \\
Group F & 25 & 93.64 & 14.277 & & \\
\hline
\end{tabular}

The ' $t$ ' value is 0.789 . It has been observed that there is no significant difference among the two groups. Therefore the null hypothesis is retained

\begin{tabular}{|c|c|c|c|c|c|}
\hline \multicolumn{6}{|c|}{ Independent samples 't' test } \\
\hline Variable & $\mathbf{N}$ & Mean & Std. Deviation & ' $t$ ' value & Level of 0.05 \\
\hline Group M & 25 & 122.20 & 16.808 & 0.070 & Not significant \\
\hline Group F & 25 & 122.48 & 10.989 & & \\
\hline
\end{tabular}

The ' $t$ ' value is 0.07 which is not significant at 0.05 level. Therefore the null hypothesis is retained and it is concluded that there is no significant difference in glucose level changes between two groups

\begin{tabular}{|lccccc|}
\hline Table 3: Pre-induction cortisol levels (in mcg/dl) \\
\hline \multicolumn{5}{c}{ Independent samples 't' test } \\
\hline Variable & $\mathbf{N}$ & Mean & Std. Deviation & 't' value & Level of $\mathbf{0 . 0 5}$ \\
\hline Group M & 25 & 11.32 & 4.230 & 0.34 & Not significant \\
Group F & 25 & 11.72 & 4.088 & & \\
\hline
\end{tabular}

The ' $t$ ' value found to be 0.34 which is not significant at 0.05 level. Therefore the null hypothesis is retained. There is no significant difference between two groups in pre induction cortisol levels

\begin{tabular}{|c|c|c|c|c|c|}
\hline \multicolumn{6}{|c|}{ Independent samples 't' test } \\
\hline Variable & $\mathbf{N}$ & Mean & Std. Deviation & 't' value & Level of 0.05 \\
\hline Group M & 25 & 19.04 & 4.826 & 2.19 & Significant \\
\hline Group F & 25 & 22.04 & 4.869 & & \\
\hline
\end{tabular}

The ' $t$ ' value found to be 2.19 which is significant at 0.05 level. Therefore the null hypothesis is rejected. The mean serum cortisol level for morphine (19.04) is lesser than mean serum cortisol level for fentanyl (22.04). There is a significant reduction of cortisol level by morphine when compared to fentanyl and it is concluded that morphine is better than fentanyl in attenuation of Intra operative stress response under General Anesthesia 


\begin{tabular}{|c|c|c|c|c|c|}
\hline \multicolumn{6}{|c|}{ Paired samples ' $t$ ' test } \\
\hline & Mean & $\mathbf{N}$ & $\begin{array}{c}\text { Std. } \\
\text { Deviation }\end{array}$ & 't' value & $\begin{array}{l}\text { Level } \\
\text { of } 0.05\end{array}$ \\
\hline \multicolumn{6}{|l|}{ Pair 1} \\
\hline $\begin{array}{l}\text { Morphine } \\
\text { (one hour after } \\
\text { induction) }\end{array}$ & 122.20 & 25 & 16.808 & 17.647 & Significant \\
\hline $\begin{array}{l}\text { Morphine } \\
\text { pre-induction }\end{array}$ & 97.12 & 25 & 16.483 & & \\
\hline
\end{tabular}

\begin{tabular}{|c|c|c|c|c|c|}
\hline \multicolumn{6}{|c|}{ Paired samples 't' test } \\
\hline & Mean & $\mathbf{N}$ & $\begin{array}{c}\text { Std. } \\
\text { Deviation }\end{array}$ & 't' value & $\begin{array}{l}\text { Level } \\
\text { of } 0.05\end{array}$ \\
\hline \multicolumn{6}{|l|}{ Pair 1} \\
\hline $\begin{array}{l}\text { Fentanyl } \\
\text { (one hour after } \\
\text { induction) }\end{array}$ & 122.48 & 25 & 10.989 & 19.658 & Significant \\
\hline $\begin{array}{l}\text { Fentanyl } \\
\text { pre-induction }\end{array}$ & 93.64 & 25 & 14.277 & & \\
\hline \multicolumn{6}{|c|}{$\begin{array}{l}\text { There is significance in the ' } t \text { ' values for both morphine and fentanyl study group. } \\
\text { It can be concluded that both the drugs have equal effect on the serum glucose } \\
\text { levels in patients undergoing surgery under general anesthesia. But when compared } \\
\text { between two groups, it is not significant }\end{array}$} \\
\hline
\end{tabular}

\begin{tabular}{|c|c|c|c|c|c|}
\hline \multicolumn{6}{|c|}{ Paired samples ' $t$ ' test } \\
\hline & Mean & $\mathbf{N}$ & $\begin{array}{c}\text { Std. } \\
\text { Deviation }\end{array}$ & 't' value & $\begin{array}{l}\text { Level } \\
\text { of } 0.05\end{array}$ \\
\hline \multicolumn{6}{|l|}{ Pair 1} \\
\hline $\begin{array}{l}\text { Morphine } \\
\text { (one hour after } \\
\text { induction) }\end{array}$ & 19.04 & 25 & 4.826 & 10.554 & Significant \\
\hline $\begin{array}{l}\text { Morphine } \\
\text { pre-induction }\end{array}$ & 11.32 & 25 & 4.230 & & \\
\hline
\end{tabular}

\begin{tabular}{|c|c|c|c|c|c|}
\hline \multicolumn{6}{|c|}{ Paired samples' ' $t$ ' test } \\
\hline & Mean & $\mathbf{N}$ & $\begin{array}{c}\text { Std. } \\
\text { Deviation }\end{array}$ & 't' value & $\begin{array}{l}\text { Level } \\
\text { of } 0.05\end{array}$ \\
\hline \multicolumn{6}{|l|}{ Pair 1} \\
\hline $\begin{array}{l}\text { Fentanyl } \\
\text { (one hour after } \\
\text { induction) }\end{array}$ & 22.04 & 25 & 4.869 & 24.388 & Significant \\
\hline $\begin{array}{l}\text { Fentanyl } \\
\text { pre-induction }\end{array}$ & 11.72 & 25 & 4.088 & & \\
\hline \multicolumn{6}{|c|}{$\begin{array}{l}\text { There is significance in the ' } t \text { ' values for both morphine and fentanyl study group. } \\
\text { It can be concluded that both the drugs have equal effect on the serum cortisol } \\
\text { levels in patients undergoing surgery under general anesthesia. But when compared } \\
\text { between two groups post induction serum cortisol levels are significantly lower } \\
\text { in morphine group compared to fentanyl group, which indicates that morphine is } \\
\text { better than fentanyl in attenuation of stress response }\end{array}$} \\
\hline
\end{tabular}

activation, and is correlated with changed blood levels of stress hormones and metabolites. ${ }^{7}$ If the stress response is prolonged it may result in exhaustion of essential components of the body, for example glucose, protein, fat and minerals leading to increase in morbidity and mortality. These responses can be modified in the perioperative period. Preoperative use of appropriate anxiolytics, maintenance of adequate hydration and nutrition reduces undue catabolism. ${ }^{8}$ The prevention of stress response during laryngoscopy; intubation and skin incision protects the myocardium. Maintenance of good depth of anesthesia and hemodynamics perioperatively reduces the stress response. Adequate postoperative analgesia reduces catecholamine release which helps in better wound healing.

Hemodynamic monitoring may not suffice for perioperative surgical stress quality estimation. The most accessible laboratory measure for monitoring of the stress response for non cardiac surgery may be blood glucose and serum cortisol.

In this study we have measured blood glucose and serum cortisol level to compare the effectiveness of fentanyl and morphine in attenuating the intra operative stress response. G Bell et al compared remifentanil, morphine and fentanyl for pain and stress control by estimating the sugar and cortisol level, and found cortisol and glucose level were very low in morphine and fentanyl group than remifentanil. ${ }^{9}$ In India remifentanil is not widely available. So we have taken fentanyl and morphine for comparison. Crozier and colleagues confirmed that site of action of benzodiazepine is at the hypothalamic-pituitary level in inhibiting serum cortisol level. In Crozier's study, all the patients were premedicated with tablet Diazepam night before surgery and Injection Midazolam was given intravenously during induction to enhance the attenuation of stress response. ${ }^{10}$ Hence we have premedicated all our patients with Diazepam and intravenous Midazolam was given at the time of induction.

Eva M Gruber et al evaluated the effect of large dose fentanyl anesthesia, with or without midazolam on stress response and concluded that midazolam does not alter hormonal or metabolic stress response in infants undergoing cardiac surgery. ${ }^{11}$ Whereas, Desborough JP et al found that midazolam significantly attenuates the stress responses to both peripheral and abdominal surgeries in adults. $^{12}$

In our study all the patients vital parameter (Heart rate, Blood pressure, arterial oxygen saturation) were monitored continuously, and documented in the study sheet at 3 minutes interval and we have found that their hemodynamics 
were maintained within normal range, and there was no significant difference in hemodynamics between two groups. In this study the effectiveness of morphine and fentanyl in attenuation of stress response during surgery under general anesthesia was compared based on serum cortisol and glucose levels. After statistical analysis both morphine and fentanyl were found to control glucose levels at the end of one hour after induction equally, and there was no statistical significance. But on analysis of the cortisol levels at the end of one hour after induction the mean serum cortisol level of morphine (19.04), was lesser than mean serum cortisol level of fentanyl (22.04). Hence morphine is found to be better in attenuating the stress response by effectively controlling the serum cortisol levels when compared to fentanyl. Patients with underlying illnesses like hypertension, diabetes, ischemic heart disease, and patients who undergo major laparatomies or cardiothoracic surgeries, in whom better attenuation of stress response is required, morphine can be preferred over fentanyl as narcotic of choice during general anaesthesia.

\section{CONCLUSION}

The care for the patient extends from the pre-operative period to the post-operative period, and to ensure that the patient leaves the hospital cured of his illness. Proper attenuation of stress response in patients undergoing surgery is essential to prevent post-operative wound infection and to reduce the morbidity. From this study it is concluded that morphine is better in attenuating the intra-operative stress response by effectively controlling the serum cortisol levels when compared to fentanyl in patients undergoing surgery under general anesthesia.

\section{ACKNOWLEDGEMENT}

We thank all senior faculties in our department of Anaesthesiology, for permitting and guiding us to conduct the study. We also thank
Dr. Thirunavukarasu, Dr. Srikanth and Mr. Susiganesan from department of community medicine for guiding us in statistical Analysis of the data.

\section{REFERENCES}

1. Desborough JP. The stress response to trauma and surgery. $\mathrm{Br}$ J Anaesth 2000; 85: 109-117.

2. Tacconi F, Pompeo E, Sellitri F and Mineo TC. Surgical stress hormones response is reduced after awake videothoracoscopy. Interact Cardiovasc Thorac Surg 2010; 10: 666-671.

3. Cok OY, Ozkose Z, Pasaoglu $\mathrm{H}$ and Yardim S. Glucose response during craniotomy: Propofol-remifentanil versus isofluraneremifentanil. Miverva Anaestesiol 2011; 77: 1141-1148.

4. Chrousos GP and Gold PW. The concepts of stress and stress system disorders. Overview of physical and behavioral homeostasis. JAMA 1992; 267: 1244-1252.

5. Hall GM. The anaesthetic modification of the endocrine and metabolic response to surgery. Ann R Coll Surg Engl 1985; 67: 25-29.

6. Mc Donald RK, Evans FT, Weise VK and Patrick RW. Effect of morphine and nalorphine on plasma hydrocortisone levels in man. J Pharmacol Exp Ther 1959; 125: 241-247.

7. Anand KJS, Hansen DD and Hickey PR. Hormonal-Metabolic stress responses in neonates undergoing cardiac surgery. Anesthesiology 1990; 73: 661-670.

8. Manorama Singh. Stress response and anesthesia-Altering the peri and post-operative management. Indian J. Anaesth 2003; 47: 427-434.

9. Bell G, Dickson U, Arana A, Robinson D, Marshall C and Morton N. Remifentanil vs fentanyl/morphine for pain and stress control during pediatric cardiac surgery. Paediatr Anaesth 2004; 14 : 856-860.

10. Crozier TA, Beck D, Schlaeger M and Wuttke W. Endocrinological changes following Etomidate, Midazolam, or Methohexitol for minor surgery. Anesthesiology 1987; 66: 628-635.

11. Gruber EM, Laussen PC, Casta, Zimmerman AA, Zurakowski $D$, Reid $R$, et al. Stress response in infants undergoing cardiac surgery: A randomized study of fentanyl bolus, fentanyl infusion, and fentanyl -midazolam infusion. Anesth Analg 2001; 92: 882990.

12. Desborough JP, Hall GM, Hart GR and Burrin JM. Midazolam modifies pancreatic and anterior pituitary hormone secretion during upper abdominal surgery. Br. J. Anaesth 1991; 67: 390-396. 